\title{
La mitología en las exequias reales de la Casa de Austria
}

Maㅗ Adelaida Allo Manero

RESUMEN. El presente artículo analiza el uso de la mitología clásica en los programas iconográficos de las exequias reales celebradas en los reinados de Felipe II, Felipe III y Felipe IV (1558-1665), proporcionando un repertorio temático exhaustivo que permite precisar cuándo y dónde aparecieron las primeras representaciones mitológicas, su cuantificación porcentual frente a otras temáticas, el proceso de reinterpretación que siguieron sus fuentes literarias e iconográficas en aras de un supuesto afán didáctico y, finalmente, su progresiva aceptación a lo largo del siglo XVII, sobre todo en los programas ideados por miembros de la Compañía de Jesús, los únicos en los que esta temática encontró un lugar de honor.

Palabras clave: Mitología, exequias reales, iconografía de los reyes Felipe II, Felipe III y Felipe IV.

RESUME. Cet article analyse l'utilisation de la mythologie classique dans les programmes iconographiques des obsèques funèbres aux temps de Felipe II, Felipe III et Felipe IV (1558-1665), et présente un rèpertoire thèmatique complet qui permet préciser les questions suivantes: le moment et les endroits où sont parûes les premiéres representations mithologiques, leur rang d'usage face à face $d^{\prime}$ 'autres thèmes, la transformation de leurs sources d'inspiration, autant littéraires que iconographiques, pour les remettre très didactiques, et à la fin, on y constate une evolution progressive de leur presence pendant le XVII ième. siècle, surtout dans les programmes inventés par les jésuites.

Mots clé: Mythologie, obsèques royals, iconographie des rois Felipe II, Felipe III et Felipe IV.

Valorar la pervivencia de la mitología clásica en las artes plásticas españolas del Renacimiento y el Barroco constituye afrontar uno de los problemas más atractivos y complejos de la Iconografía o estudio de las imágenes simbólicas elaboradas durante la Edad Moderna. Su introducción aparece vinculada a un Renacimiento en el que se llevó a cabo una revalorización de las imágenes y las formas clásicas ligadas a corrientes de pensamiento humanístico, pasando a figurar tempranamente en la escultura del arte civil y religioso y, más restrictivamente, en la pintura. A pesar de la Contrarreforma, los temas mitológicos no desaparecieron por completo de las manifestaciones artísticas barrocas, si bien su presencia en muchos casos se alejó notablemente de las razones, métodos de uso e incluso del significado que habían logrado alcanzar en los complejos programas iconográficos del humanismo.

Se viene afirmando, y no sin razón, que además de su aparición en el arte monumental y en la pintura, los asuntos de la fábula pagana encontraron un marco concreto en el que experimentaron un gran desarrollo y éste no fue otro que el Arte 
Efímero, un auténtico banco de pruebas o gran base de datos donde se puede examinar el uso y la utilización de esta peculiar y restrictiva iconografía, habida cuenta de la extraordinaria riqueza simbólica de los programas iconográficos que ornaron sus arquitecturas provisionales mediante numerosas estatuas y pinturas alegóricas, jeroglíficos y composiciones poéticas, en las que las imágenes clásicas y las religiosas terminaron por configurar, como se sabe, un auténtico compendio de la cultura humanística del Renacimiento y del Barroco, el cual fue utilizado como instrumento de divulgación cultural y de difusión de valores éticos y morales.

Ahora bien, el estado actual de los estudios iconográficos sobre Arte Efímero impide establecer visiones de conjunto incluso en torno a cuestiones básicas como: la aparición de las primeras representaciones mitológicas, su contexto celebrativo, la cuantificación porcentual entre los distintos tipos de temáticas (bíblica, histórica, astrológica, emblemática, mitológica, etc.), lo que permitiría conocer en qué medida fue utilizada la Mitología frente a las demás; la progresión y evolución de alguno de sus asuntos más destacados a lo largo del Renacimiento y el Barroco, o incluso un repertorio básico de temas y asuntos, en este caso, mitológicos.

Los estudios realizados sobre las ceremonias públicas más relevantes de la primera mitad del siglo XVI parecen confirmar que, frente a la decidida presencia de los temas mitológicos en el conjunto de entradas triunfales de Carlos V en Italia y Francia, así como en las organizadas posteriormente a Felipe II en sus viajes a Italia, Alemania y Países Bajos $(1548-1551)^{1}$, la

\footnotetext{
${ }^{1}$ Fêtes et cérémonies au temps de Charles Quint. Rérunies et présentées par Jean Jacquot, Paris, 1975. F. J. PIZARRO, Arte y espectáculo en los viajes de Felipe II, Madrid, 1999, pp. 104-120.
}

aparición de tales asuntos en las entradas reales organizadas en España fue más tardía y mucho más lenta. Es verdad que pueden ser encontradas alusiones a elementos y personajes tomados de la fábula pagana en justas y torneos, en representaciones escénicas y demás regocijos populares en fechas tan tempranas como 1527, con motivo de las fiestas organizadas en Valladolid por el nacimiento de Felipe II, o posteriormente en 1543 y 1544 en las fiestas que tuvieron lugar en Salamanca y Valladolid, respectivamente, por el matrimonio de Felipe II con María Manuela de Portugal. Sin embargo, las entradas reales más significativas del reinado de Carlos $\mathrm{V}$ no se hicieron eco de este código iconográfico a pesar de haber recurrido ampliamente al uso de la alegoría y el jeroglífico. Será preciso esperar a los primeros años del reinado de Felipe II para comprobar la decidida incorporación de la temática mitológica en los programas iconográficos de entradas reales, como así lo acreditan las realizadas en Alcalá de Henares (1559) y Toledo (1560) con motivo del matrimonio de Felipe II con Isabel de Valois, y cuya novedad, al parecer, se vio rodeada de algunas críticas ${ }^{2}$, tratándose a partir de entonces de un recurso que irá in crescendo a lo largo de su propio reinado.

De esta manera la Mitología se habría incorporado más tardíamente que la Historia, y en particular la de Roma, dentro de las principales fuentes clásicas utilizadas por los humanistas para idealizar los complejos contenidos programáticos de estos

\footnotetext{
${ }^{2}$ F. J. PIZARRO, op. cit., p. 150, nota 54 sobre la entrada de Felipe II e Isabel de Valois en Toledo en 1559.

${ }^{3}$ Además de las entradas mencionadas, Alcalá de Henares (1559) y Toledo (1560), véanse los programas iconográficos de las celebradas en Valladolid (1565), Segovia y Madrid (1570), Sevilla (1570) y Lisboa (1581). Vid. Bibliografía especializada en La fiesta cortesana en la época de los Austrias, M.L. LOBATO Y B.J. GARCíA (coords.), Valladolid, 2003, pp. 320-326 y 337-340.
} 
eventos, habida cuenta del importante conjunto de entradas triunfales "all'antica" que, al menos desde 1507, ya habían sido organizadas en España en honor de Fernando el Católico ${ }^{4}$.

Sin embargo, una vez aceptada la temática mitológica $\mathrm{y}$, naturalmente, convenientemente moralizado su uso, llegó a convertirse en uno de los temas más destacados y preponderantes de los programas iconográficos desarrollados en las entradas triunfales organizadas a lo largo de todo el siglo XVII, como así lo acreditan las realizadas en honor de las respectivas entradas en la corte madrileña de las reinas Margarita de Austria, Mariana de Austria, Maria Luisa de Orleáns y Mariana de Neoburgo ${ }^{5}$.

Ahora bien, paralelamente a las entradas triunfales, la celebración de exequias reales ofrece un rico repertorio iconográfico en el que también se puede examinar el tratamiento de la temática mitológica. Por esta razón, intentaremos dar respuesta en esta ocasión a alguna de las interrogantes planteadas anteriormente, precisando más concretamente cuándo, dónde y cómo fue utilizada la mitología clásica en este largo periodo de nuestras exequias reales.

Pero antes de abordar la evolución que siguieron los temas mitológicos en estos programas iconográficos, consideramos oportuno exponer el contexto programático en el que fueron incluidos, teniendo presente que, en esencia, dichos programas

\footnotetext{
${ }^{4}$ M. FALOMIR FAUS, "Entradas triunfales de Fernando el Católico en España tras la conquista de Nápoles", La visión del mundo clásico en el arte español. Actas de las VI Jornadas de Arte, Madrid 15-18 Diciembre, 1992. Madrid, 1993. T. KNIGHTON Y C. MORTE GARCÍA, "Ferdinand of Aragon's entry into Valladolid in 1513: the triumph of a christian king", Early Music History, vol. 18, 1999, pp. 119-163.

${ }^{5}$ Vid. Bibliografía especializada en La fiesta cortesana en la época de los Austrias, M. L LOBATO Y B. J. GARCíA (coords.), Valladolid, 2003, pp. 320-326 y 337340
}

persiguieron dos objetivos básicos: el primero estuvo destinado a establecer un elogio del difunto, sirviendo de oportunidad y ocasión para glorificar la Monarquía de los Austrias y aumentar el reconocimiento del pueblo, mientras que el segundo pretendió extraer una lección moral en torno a la muerte ${ }^{6}$. Ambos aparecen claramente explicitados por los correspondientes autores de los libros de exequias y sobre ellos insisten machaconamente una y otra vez, plagando sus discursos de múltiples matices enriquecedores como los siguientes.

El elogio del difunto siempre se llevó a cabo de forma similar, dado que todos los programas ofrecen en esencia una exaltación del ejercicio político apoyado en una práctica virtuosa, tratándose en consecuencia de actuaciones del monarca puestas al servicio de la fe y la religión católica; se trata, en suma, de configurar la imagen de gobernante ejemplar. Esta condición particular será la que sirva finalmente para justificar el logro de la inmortalidad a través del disfrute de la gloria eterna. Estos dos temas puntuales -ejercicio virtuoso y triunfo- se completaron a menudo con otros, como el noble origen del muerto, (ilustres antepasados, progenie y familia) para justificar su legitimidad al trono, el origen divino de tal derecho, la universalidad de su poder y circunstancias de su muerte particular (fecha, enfermedad y causa, ejemplaridad de conducta, signos o pronósticos, dolor del cónyuge, llanto de los súbditos, de la ciudad patrocinadora de la ceremonia y de toda la Monarquía).

En cuanto a la lección doctrinal reflejada en estos conjuntos funerarios se apoya en dos visiones distintas del tema de la Muerte. La primera insiste sobre aspectos

${ }^{6}$ A. ALLO, "Imagen y propaganda: los programas iconográficos para exequias reales", Exequias de la Casa de Austria en España, Italia e Hispanoamérica, Zaragoza, Universidad, 1993, pp. 99-110.
} 
tan concretos como su poderío inquebrantable, su rápida e inesperada llegada, su rigor y fatalidad, su impiedad, su poder sobre todas las cosas terrenas, etc., permaneciendo muy próxima a la sensibilidad que había caracterizado su expresión en la tradición medieval. Esta concepción de la Muerte convivió asimismo con la idea cristiana de la muerte, entendida como fin de la existencia humana y paso obligado a la consecución de la gloria celestial, del triunfo final, de la inmortalidad eterna. Los programas iconográficos desarrollados en los túmulos y en los jeroglíficos desde 15581700 aglutinaron frecuentemente ambas visiones sobre este tema, si bien esto no impidió el fortalecimiento de una $\mathrm{u}$ otra visión a través de la especial disposición de las imágenes destinadas a representarla. En líneas generales se observa que la idea fatalista, poderosa y rigurosa de la Muerte prevaleció con bastante vigor hasta el reinado de Felipe IV, y que a partir de sus exequias, esta visión, aunque no desapareció, cedió paso a la consideración de la muerte como camino obligado para la obtención del triunfo final, el difunto triunfa sobre la muerte y alcanza la gloria eterna.

Para expresar plásticamente en forma de esculturas alegóricas y sobre todo de "jeroglíficos" (emblemas, empresas, enigmas, etc.) estos contenidos programáticos fueron utilizadas multitud de fuentes: los clásicos grecolatinos, la Biblia, la Historia, la Astrología, la Emblemática y naturalmente la Mitología. Ahora bien, una mitología, como corresponde a este momento, moralizada, interpretada, de manera que sus dioses y héroes se presentan como ejemplos de virtud y defensores del bien.

Los autores de estas composiciones simbólicas no dudan en citar en muchos casos sus fuentes de inspiración iconográfica, haciendo gala de su erudición. Y así, a lo largo de la cronología estudiada se han encontrado alusiones a los manuales mito- lógicos por excelencia: Cartari ${ }^{7}$, Juan Pérez de Moya ${ }^{8}$, fr. Baltasar de Vitoria ${ }^{9}$, Giraldi, Conti y sin duda el más citado, las Metamorfosis de Ovidio ${ }^{10}$, a través de las distintas ediciones moralizadas de las que fue objeto. Además de estos manuales, los autores de nuestros jeroglíficos se sirvieron de muchos libros de emblemas, en los que la mitología, como se sabe, ocupó un papel destacado, y así aparecen citas expresas, entre otros autores, a Alciato, Juan de Borja, Juan de Horozco, Sebastián de Covarrubias, Nicolás Reusner, Gabriel de Rollenhagen, y Aquiles Bocchio ${ }^{11}$. No podemos cerrar esta breve alusión a las fuentes de nuestros jeroglíficos mitológicos sin mencionar la gran enciclopedia de símbolos de la época, la Hieroglífica de Piero Valeriano ${ }^{12}$.

La aparición y desarrollo de los temas mitológicos en los programas iconográficos de exequias reales en España e Hispanoamérica ofreció la siguiente evolución.

\section{REINADO DE FELIPE II (1558-1598).}

Las exequias reales de este periodo corresponden a las celebradas en honor de

-

${ }^{7}$ V. CARTARI, Le imagini de i Dei degli Antichi, Venecia, 1556 (consultada ed. Lione, 1581).

${ }^{8}$ J. PÉREZ DE MOYA, Philosofía Secreta, Madrid, 1585 (consultada ed. Barcelona, 1977).

${ }^{9}$ B. DE VITORIA, Teatro de los Dioses de la Gentilidad, Salamanca, 1620-1623.

${ }^{10}$ Ovidio, Metamorfoseo Vulgare, (consultada edición de A. RUIZ ELVIRA, Barcelona, 1964-69).

11 A. Alciato, Emblemas, Madrid, Augsburgo, 1531. (consultada ed. Editora Nacional, 1975). J. DE BORJA, Empresas Morales, Praga, 1581 (consultada Bruselas, 1680). J. DE HOROZCO y COVARrubias, Emblemas Morales, Segovia, 1589. S. DE CovarRUBIAS OROZCO, Emblemas morales, Madrid, 1610. N. REUSNER, Emblemata, Francoforti, 1581. G. DE ROLlENHAGEN, Nucleus Emblematum selectissimorum, Arnheim, 1611. A. BocCHI, Symbolicarum Quaestionum, Bolonia, 1555.

${ }^{12}$ I. P. VALERIANO, Hieroglyphica sive de sacris aegyptiorum aliarumque gentium literis commentarii, Basilea, 1556. 
Carlos V (1558), el príncipe don Carlos (1568), la reina Isabel de Valois (1568 bis) y la reina Ana de Austria (1580).

Si se centra la atención en los programas iconográficos de las 16 ceremonias conocidas sobre las exequias del emperador Carlos $\mathrm{V}^{13}$, se comprobará que, a pesar de las múltiples y constantes referencias a la Antigüedad Clásica que figuran en muchos de ellos, sólo existe una iconografía propiamente mitológica en dos, concretamente, en los desarrollados para los túmulos de Valladolid y Méjico ${ }^{14}$, siendo además mucho más representativa la presencia de esta temática en el programa mejicano, dado que conformó el $10 \%$ de las composiciones simbólicas elaboradas.

A pesar de que el conocimiento sobre el resto de las exequias celebradas durante este periodo resulta más exiguo - 6 son las relaciones conocidas sobre las exequias reales del príncipe Carlos, 7 sobre las de la reina Isabel de Valois y 5 sobre las de la reina Ana de Austria ${ }^{15}$ - sus programas iconográficos sirven de base para establecer una valoración certera ante la problemática que nos ocupa, habida cuenta que resulta imposible encontrar en alguno de ellos más de una composición mitológica.

\footnotetext{
${ }^{13}$ A. Allo, "Exequias del emperador Carlos V en la Monarquía Hispana", Carlos V y las Artes. Promoción artística y familia imperial, M.J. REDONDO CANTERA Y M.A. ZALAMA (coords.), Valladolid, 2000, pp. 261-281. Con bibliografía sobre los estudios iconográficos realizados sobre estos programas.

${ }^{14}$ Programas estudiados por: J. J. ABELLA, “El túmulo de Carlos V en Valladolid", BSAA de Valladolid, 44, 1978, pp. 177-200. S. SEBASTiáN, “El túmulo de Carlos V", Homenaje a Justino Fernández, México, 1977. F. CHECA, Carlos V y la imagen del héroe en el Renacimiento, Madrid, 1987, pp. 259-273. S. SEBASTIÁn, Arte y Humanismo, Madrid, 1978, pp. 312-317.

15 A. ALLO, 1993, pp. 273-303. Sobre el programa sevillano de Isabel de Valois: V. LLEÓ CAÑAL, Nueva Roma: mitología y humanismo en el renacimiento sevillano, Sevilla, 1979, p. 147.
}

En consecuencia, podemos afirmar que las composiciones mitológicas aparecidas en esta época fueron escasas y excepcionales, razón por la cual el repertorio de las mismas resulta muy limitado $y$, como se verá seguidamente, algo reiterativo.

Hércules dentro del mar con la espalda vuelta a España y su rostro mirando a Occidente, con dos columnas acompañadas del lema Plus Ultra bajo sus brazos. Con el mote "Imperium sine fine dedi". (Méjico, 1559). Significó la voluntad del emperador en su gran aventura ultramarina.

Hércules, como se sabe, llevó a cabo alguna de sus hazañas en Hispania $y$, precisamente, en recuerdo de todas ellas, ejecutó la última, que al decir de fr. Baltasar de Vitoria consistió en colocar dos grandes columnas en Cádiz, escribiendo entre ellas el lema "Non Plus Ultra" por parecerle que aquí se acababa el mundo. Los historiadores de los siglos XVI y XVII identificaron las dos columnas de esta hazaña con dos grandes montículos, los montes Calpe y Abyla, utilizados para cerrar el estrecho. Este emblema mejicano tiene su fuente de inspiración en la divisa que el italiano Luigi Marliano inventó para Carlos V cuando todavía era duque de Borgoña, la cuál, a su vez, se sirvió de la iconografía de esta conocida hazaña hercúlea, de la que tan sólo tomó las dos monumentales columnas, aunque no así el mote "Non plus ultra"16. De esta forma, Carlos V, al igual que Hércules, habría logrado redefinir el límite conocido del mundo en su época, yendo más allá que el mismo héroe.

Hércules luchando con la hidra de Lerna. Con el mote "Maximum, invictissimum, religiosissimum Carolum quintum,

${ }^{16}$ R. LÓPEZ TORRIJOS, La mitología en la pintura española del Siglo de Oro, Madrid, 1985, pp. 121-122. Realiza una buena síntesis sobre los estudios de E. Rosenthal en torno a este asunto.
} 
capitibus pullulantium unicum percussorem domitoremque, hoc monumento atque labore meo in ventura saecula vaticinor". (Méjico, 1559). Significó la lucha del emperador contra la herejía.

La fuente de inspiración iconográfica de esta composición se encuentra en Alciato, quien utilizó la hazaña hercúlea aquí representada para significar el triunfo sobre los sofistas: "... y desata el lazo y desbarata a los $\operatorname{sofistas}^{\prime 17}$ (fig. 1). No cabe la menor duda de que uno de los mayores sofismas del reinado del emperador fue la doctrina de Lutero, por lo que cabría interpretar que se trataba de una temprana imagen de Carlos $\mathrm{V}$ venciendo a la herejía ${ }^{18}$. Esta lectura cuenta con un importante refrendo de fuentes iconográficas y literarias posteriores a las exequias mejicanas, ya que el tema de Hércules venciendo a la hidra de Lerna como símbolo de lucha religiosa y triunfo sobre los herejes figura, entre otros, en Damián de Fonseca, Marco Antonio Orti o Juan Francisco Fernández de Heredia ${ }^{19}$. Según el jesuita Juan Antonio Jarque la fuente literaria de este simbolismo se encuentra en San Jerónimo: "Monstrum en latín, y lo que suena en romance, llamó San Jerónimo con toda propiedad a la Herejía ....Y después de aver hecho largo arancel de Monstruos diferentes que refieren las Historias Sagrada y Profana, como Centauros, Sirenas, Cancerbero, Aves estinfálidas tan perniciosas a la Arcadia, jabalí de Erimanto,

-

${ }^{17}$ Alciato, op. cit., embl. CXXXVII, p. 211.

${ }^{18}$ R. LAMARCA RUIZ DE EGUILAZ, “La representación del no creyente en los emblemas de las decoraciones festivas barrocas. De la bestia del Apocalipsis de San Juan a la tradición hercúlea de la hidra de Lerna", S. LÓPEZ POZA y Nieves PeNA, eds. La fiesta. Actas del II Seminario de Relaciones de Sucesos (A Coruña, 1315 de julio de 1998), Ferrol, 1999, pp. 187-199.

${ }^{19}$ D. FONSECA, Justa expulsión de los moriscos de España, Roma 1612. M. A. ORTI, Siglo quarto de la conquista de Valencia, Valencia, 1640. J. F. FERNÁNDEZ DE HEREDIA, Trabajos y afanes de Hércules, floresta de sentencias y exemplos, Madrid, 1682. león Nemeo, Quimera triforme, Hidra de siete cabeças, Caco de Virgilio, Gerión de tres cabeças, Gerolyficas todas de la Herejía..." ${ }^{20}$.

Laberinto de Dédalo con un clavo en la puerta y un ovillo colgado del clavo. Con el mote "Difficillissima sagacitate vicit". (Méjico, 1559). Significó, según su autor, Cervantes de Salazar, la prudencia y sagacidad del emperador, que triunfó en muchas cosas sin el uso de la fuerza.

Este significado del mito de Teseo se encuentra, en parte, en la interpretación de Juan Pérez de Moya, quien afirma del héroe ser símbolo del hombre perfecto, prudente y sagaz, que sigue el conocimiento de sí mismo y sale del mundo con maravillosa victoria $^{21}$.

Apolo coronado de laurel, con un libro en las manos, sobre los muros de la ciudad de Méjico. Con el mote "Felix Imperium omnis virtus ambit". (Méjico, 1559). Significó la protección cultural que obró el emperador en aquella ciudad, fundando su universidad.

El simbolismo de Apolo como dios de la sabiduría por haber sido el inventor de la medicina, se encuentra en Ovidio y Boccaccio $^{22}$, y sirviéndose del mismo se equiparó a Carlos V con esta deidad.

Tres doncellas aladas con serpientes en la cabellera y sangre goteando de sus ojos, con la letra "Euménides". Bajo ellas, la batalla de Tenochtitlán, con el mote "Ex dificultate gloria". (Méjico, 1559). Significó la resistencia que opusieron los indios a las

\footnotetext{
${ }^{20}$ J. A. JARQUE, Augusto llanto, finezas de tierno carino y reverente amor de la Imperial Çiudad de Caragoça en la muerte del rey su señor Filipe el Grande, Quarto de Castilla y Tercero de Aragón. Zaragoza, Diego Dormer, 1666, pp. 259-260.

${ }^{21}$ J. PÉREZ DE MOYA, op. cit. IV, 26.

22 OvIDIO, op. cit., II, V.
} 
tropas españolas en la última y decisiva batalla para conquistar Méjico.

La iconografía de las tres Furias infernales como doncellas con serpientes en sus cabelleras y sangre goteando de sus airados ojos, la recoge Vicenzo Cartari, y es este mismo autor quien proporciona la fuente precisa de la iconografía plasmada en el emblema mejicano, al afirmar que Virgilio, en el libro 12, les añade las alas porque siempre se encuentran delante de Júpiter dispuestas a ser enviadas a los hombres como símbolo de muerte, guerra, peste o cualquier desgracia grave $e^{23}$ (fig. 2).

Una columna llena de inscripciones dentro del río Leteo. Con el mote "Contra oblivionem, antidotum virtus". (Méjico, 1559). Según su autor significó que, contra la fuerza del olvido, permanecerá la memoria de la virtud del emperador.

Son muchos los autores que, al tratar los ríos del infierno, señalan el Leteo como el río del Olvido, entre ellos Cartari ${ }^{24}$. Por su parte, Piero Valeriano presenta la columna como símbolo de los hechos heroicos, es decir, de la virtud heroica ${ }^{25}$.

Las Parcas (Sevilla, 1545; Valladolid, 1558; Villa de Madrid, 1568; Toledo, 1568bis; Sevilla, 1568bis).

Se trata de Cloto, Láquesis y Átropos, las tres diosas romanas del destino que controlan el hilo de la vida, que la primera hila, la segunda devana y la tercera corta, simbolizando así el nacimiento, la vida y la muerte de los humanos. Su presencia en los emblemas de estos programas iconográficos siempre se centra en contextos de vánitas, expresando la fragilidad y rapidez de la vida, así como que la muerte lo consume todo. Su iconografía ofreció dos variantes.

\footnotetext{
23 CARTARI, op, cit. p. 245.

24 CARTARI, op, cit. p. 244.

${ }^{25}$ P. VALERIANO, op. cit. L. XLIX.
}

La más habitual fue la tradicional, mediante tres matronas con rueca, huso y tijeras. Pero también se ha podido constatar el uso de otra menos frecuente, recogida y explicada por Cartari ${ }^{26}$ : Cloto como joven semidesnudo llorando, Láquesis como niño alado y Átropos como calavera (fig. 3).

Caída de Faetón (Méjico, 1559; Salamanca, 1568bis).

Faetón, el "luminoso", fue hijo de Helios y Clímene; su padre le permitió guiar su propio carro a través del cielo por un solo día, pero faltándole fuerza al joven, los caballos se desviaron de su curso y poco faltó para que incendiara la tierra. Zeus lo mató con un rayo y lo arrojó al río Eridano. Alciato ya presentó a Faetón como ejemplo del envanecimiento que conduce a la propia destrucción, ${ }^{27}$ (fig. 4), figurando posteriormente con el mismo significado en la tratadística simbólica de la época (Reusner, Pérez de Moya, Sebastián de Covarrubias $)^{28}$.

En Méjico, Faetón fue representado como contrapunto de Carlos V, pues frente al carro abrasado y destruido del hijo del Sol se pintó al emperador en otro carro, bien erguido y guiando los caballos con una vara, con el lema "Se regens, rexit", expresando "cómo por regirse a sí César primero, rigió y gobernó prudentemente sus reinos y señoríos". En la composición salmantina dedicada a la muerte de la reina Isabel de Valois, el tema de Faetón apareció como fondo de una composición en la que, en primer término, fue representado un eclipse de luna. Dicho eclipse simbolizó la muerte de la reina, mientras que nuestro tema bien pudo aludir a la muerte del príncipe don Carlos, acaecida tres meses antes, dadas las

\footnotetext{
${ }^{26}$ CARTARI, op. cit. p. 257.

27 Alciato, op. cit. embl. LVI, p. 120.

${ }^{28}$ REUSNER, op. cit., III, 32. S. COVARRUBIAS, op. cit., cent. 2, embl. 69. J. PEREZ DE MOYA, op. cit., 2, 18.
} 
conocidas circunstancias que envolvieron tanto la vida como la muerte del joven, pues, como es sabido, fue arrestado y acusado de entendimiento con los rebeldes holandeses. Su autor fue el entonces racionero de la catedral salmantino Sebastián de Covarrubias y Horozco.

\section{REINADO DE FELIPE III (1598- 1621).}

Tan escasas como lo habían sido en el reinado anterior, van a ser ahora las representaciones mitológicas en los programas de exequias reales. Si se analizan las composiciones simbólicas realizadas para las exequias de Felipe II, y son muchas las relaciones conservadas ${ }^{29}$, sólo se ha encontrado mitología en los programas iconográficos de los túmulos construidos en Sevilla y Zaragoza y, por lo que respecta al caso zaragozano ${ }^{30}$, conviene considerar que tan sólo hubo una composición simbólica dentro de un conjunto de 26 , que se trató de una de las divisas del monarca y que fue colocada en el techo del baldaquino del túmulo, ocupando el lugar del tradicional escudo de armas del difunto, lo que lleva a concluir que su presencia no fue en absoluto significativa. Muy parecida resulta la conclusión que podemos extraer del aparato fúnebre sevillano, cuyo complejo y exhaustivo programa iconográfico tan sólo exhibió tres escuetos emblemas de temática mitológica: Hércules con el mundo sobre sus hombros, alusivo a los trabajos del rey, Hércules con las dos columnas, también alusivo al monarca y, finalmente, la empresa filipina con el carro del Sol con sus cua-

\footnotetext{
-

${ }^{29}$ A. ALLO, 1993, pp. 313-345.

${ }^{30}$ Estudiado por J.F. EsTEBAN, “Mensaje simbólico de las exequias reales realizadas en Zaragoza en la época del Barroco", Seminario de Arte Aragonés, XXXIV, 1981, pp. 121-150 y J. B. SCOTT, "The catafalques of Philip II in Zaragoza", Studies in Iconography, V, 5, 1979, pp. 107-134.
}

tro caballos saliendo de Oriente entre grandes resplandores ${ }^{31}$.

Idéntica situación se repite en las honras fúnebres posteriores. De las 16 relaciones de exequias de la reina Margarita de Austria $^{32}$, fallecida en 1611, tan sólo figuran jeroglíficos de temática mitológica en los programas desarrollados en Córdoba ${ }^{33}$ y en Zaragoza, y su relación porcentual con respecto al conjunto resulta meramente testimonial, puesto que en ambos casos es muy similar: uno entre 14 en el caso cordobés y uno entre 16 en el zaragozano.

En 1621, con motivo de las exequias de Felipe III, el panorama empieza a cambiar de forma significativa: dos son los jeroglíficos que se hicieron en Sevilla, también hubo composiciones mitológicas en el programa de la Villa de Madrid y en Zaragoza incluso llegaron a surgir duras críticas, precisamente, por la proliferación que tales imágenes habían tenido en su programa iconográfico ${ }^{34}$.

Además de este uso discreto, se inicia, como veremos seguidamente, un proceso de reinterpretación de las fuentes utilizadas, que afecta tanto a las de carácter literario como a las puramente iconográficas, en una búsqueda desmedida por crear composiciones originales y ante todo muy didácticas, cuyas cotas más geniales, no obstante, darán sus mejores frutos en el reinado siguiente. Veamos algunos ejemplos.

\footnotetext{
${ }^{31}$ V. LLEÓ CAÑAL, op. cit., p. 142.

${ }^{32}$ A. ALLO, 1993, pp. 349-393.

${ }^{33}$ F. MORENO CUADRO, Las celebraciones públicas cordobesas y sus decoraciones, Córdoba, 1988, pp. 32-40.

${ }^{34}$ P. AlBINIANO DE RAJAS, Lágrimas de Çaragoça en la muerte de Filipo, Rey II de Aragón deste apellido y Exequias que con aparato real a su memoria celebró. Çaragoça, Juan de Lanaja, 1621.
} 
Apolo-Sol en su cuadriga de caballos sobrevolando el mundo. Con el mote "Iam illustravit omnia" (Zaragoza, 1598).

La composición copia directamente la iconografía de la empresa que figuró en el reverso de la medalla realizada por Jaccopo de Trezzo al cumplir el rey 28 años y que, según Ruscelli, significó "el rey alumbrando al mundo con la fe católica y la religión cristiana".

Mercurio saliendo de entre unas nubes y cogiendo una rama de la hierba Moli de la boca del cadáver del rey. ( Zaragoza, 1598).

Según explica el autor de la relación el jeroglífico aludía a la elocuencia del rey y su fuente de inspiración se encuentra en Alciato $^{35}$, que trata el tema para explicar que la erudición requiere esfuerzo o que el discurso elocuente es dificultoso (fig. 5). La hierba Moli es una especie de ajo con hermosas flores que cuesta mucho arrancar y que se utilizaba contra los encantamientos.

La reina Margarita cortando con una sierra una de las tres cabezas del gigante Geriones, mientras una mano que salía de una nube detenía la guadaña de una Muerte que amenazaba a la reina. Con el mote "Ne totum pereat, melius est abscindere parte/ Donec abscindat manum, quae scandalizat" y la letra "Detén Muerte la guadaña/ Hasta que la mano la sierre/ y los Moriscos destierre,/ Que escandalizan a España".( Córdoba, 1611)

La reina aparece como nuevo Hércules en la conocida hazaña en la que el héroe mata al gigante de tres cuerpos, tres cabezas y un corazón que, según algunos, vivía en España. Según su autor, aludió a la intervención de la reina en el decreto de expulsión de los moriscos (1609). La elección

${ }^{35}$ AlCIATO, op. cit., embl. CLXXXI, p. 208. de este tema iconográfico podría parecer a todas luces recurrente, máxime si se tiene presente que el significado de Geriones en la emblemática es el de concordia, fuerza en la unidad, tal y como lo presentan Alciato, Reusner, Rollenhagen o Fernández Here$\mathrm{dia}^{36}$. No obstante, se encuentra bastante justificado si se recuerda la interpretación que San Jerónimo hacía de todos los monstruos de la fábula clásica en general, y entre ellos Geriones, para simbolizar a través de cada uno la herejía.

Águila volando hacia el cielo con una perla en el pico. Con el mote "Iustus expectat" y la letra "La gracia que os alumbró/ Ganimedes, Margarita/ oy de los hombres os quita/ y da el cielo que os ganó". (Zaragoza, 1611).

El epigrama que acompañó a este jeroglífico constata que se trataba de la reina, quien, como Ganímedes, fue raptada por la gracia divina. Como se sabe, el rapto de Ganímedes fue una de las metamorfosis de Júpiter más difícil de moralizar, pues no en vano relataba el amor del dios adulto por un joven adolescente de idéntico sexo. El mito pasó a simbolizar el arrebato místico del alma pura por Dios y Ganímedes se convirtió en símbolo de los elegidos por Dios, arrebatados del mundo en su juventud (Alciato (fig. 6), Bocchio, Rollenhagen, J. Horozco $)^{37}$. Por lo que respecta a la representación de la reina a través de una perla, recuérdese que "margarita" en latín significa perla. Además, Plinio, explicando su simbolismo, destaca su origen celestial, ya que la ostra es fecundada por un rocío celestial cuando el sol está en el cenit ${ }^{38}$. De

\footnotetext{
${ }^{36}$ AlCiATO, op. cit., embl. XL, p. 204. J. F. FERNÁNDEZ HEREDIA, op, cit.

${ }^{37}$ Alciato, op. cit. embl. IV, p. 85. J. DE HOROZCO, op. cit., III, embl. 25. A. BOCCHI, op. cit. III, 78. G. ROLLENHAGEN, op. cit., II, 22.

38 PLINIO, Historia Natural, Madrid, Luis Sánchez, 1624, IX, XXXIV.
} 
manera que, teniendo en cuenta este nuevo matiz, en el jeroglífico también se aludiría implícitamente al origen celestial de la realeza: la reina, que procede del cielo, vuelve a él.

Júpiter sobre su águila aplacando la rebelión de los Gigantes. Con el mote "Alitis opus" y la letra "Por él inclinó el Danubio/ La frente al César triunfante / Del Palatino arrogante". (Sevilla, 1621).

Para vengar la derrota de los Titanes, los Gigantes se enfrentaron a los Olímpicos $\mathrm{y}$, según algunos autores (Apolodoro, Hesíodo), arrojaron grandes piedras y teas encendidas contra el cielo o, de seguir a Ovidio, colocaron montañas unas encima de otras para poder llegar hasta el cielo. Pero Júpiter los destruyó con sus rayos, provocando su aplastamiento. En la literatura emblemática este tema pasó a simbolizar los peligros de sedición, la guerra, y, apoyándose en el mismo, el autor del jeroglífico explica que significó la rebelión del elector palatino frente al emperador de Austria, vencido en la batalla de la Montaña Blanca (1620) con la ayuda de tropas españolas.

Una fortaleza al lado de un manzano dorado por el que trepaba un león coronado ante la presencia de un fiero dragón saliendo del mar. Con el mote "Verus Alcides" y la letra "Mi ley entregó a Alarache/ Que menor fruto no espera/ Su liberal sementera". (Sevilla, 1621).

Según el autor, el jeroglífico aludió a la victoria naval de Larache (1610), pues este enclave fortificado, al igual que el jardín de las Hespérides, estuvo situado al pie del Atlas (Marruecos). Al igual que en otros ejemplos, la elección del tema iconográfico es muy recurrente, habida cuenta del significado simbólico tan distinto que este asunto posee en la literatura simbólica del mo- mento $^{39}$. En esta ocasión en concreto, dicha elección se basa en la idéntica ubicación geográfica del fuerte de Larache y el mismísimo jardín de las Hespérides, lo que lleva a equiparar una victoria naval de Felipe III con una de las hazañas de Hércules más conocidas.

\section{REINADO DE FELIPE IV (1621- 1665).}

A pesar de que sería erróneo hablar de triunfo de la mitología en este reinado, sí es verdad que el análisis de su uso en los programas iconográficos de exequias reales revela una mayor aceptación que en los periodos anteriores. Esta aparición se hace extensiva además a cualquier lugar de la geografía española, no figurando relegada en exclusividad a los centros culturalmente más avanzados.

De las 12 relaciones de exequias de la reina Isabel de Borbón (1644), se observa la aceptación de asuntos mitológicos en cinco de los programas iconográficos descritos en ellas: corte de Madrid, Villa de Madrid, Logroño, Granada y universidad de Salamanca, con una presencia destacada, fundamentalmente, en los dos últimos ${ }^{40}$.

En cuanto a los programas iconográficos de las exequias del príncipe Baltasar Carlos (1646), el conocimiento que poseemos en la actualidad es poco representativo $^{41}$, pero de los tres que se conocen de forma exhaustiva, dos revelan una acepta-

\footnotetext{
${ }^{39}$ J. F. FERNÁNDEZ HEREDIA, op. cit., “conocimiento y trato con las naciones".

${ }^{40}$ A. Allo, 1993, pp. 461-510. Los programas de Granada y Salamanca estudiados por: F. MORENO CUADRO, "Estructura simbólica del túmulo de Isabel de Borbón en la Capilla Real de Granada", BSAA de Valladolid, XLV, 1979, pp. 462-469 y E. MONTANER, "The last tribute to Isabella of Bourbon at Salamanca", Journal of the Warburg and Courtland Institutes, 60, 1997, pp. 164-193.

${ }^{41}$ A. ALLO, 1993, pp. 515-534.
} 
ción testimonial, que se cifra en un único jeroglífico de temática mitológica en cada programa: corte de Madrid y Zaragoza.

Mención aparte merece el programa que ostentó el túmulo construido en Toledo por el cardenal infante D. Fernando de Austria (1642), en el que la mitología ocupó un lugar destacado. Igualmente, se aprecia un uso alcista de esta temática en las exequias reales del monarca Felipe $\mathrm{IV}^{42}$. Sin embargo, y como se podrá demostrar seguidamente, ninguna ciudad española hizo gala de una afición tan decisiva por estos asuntos como Zaragoza, cuyos programas iconográficos fueron elaborados sistemáticamente por el Colegio de la Compañía de Jesús.

Veamos seguidamente un repertorio selectivo de este periodo.

Hércules Gálico. (Toledo, 1642). Significó la gran elocuencia del cardenal infante D. Fernando de Austria.

Se trata de una cultísima imagen bien conocida y estudiada. Corresponde a la identificación de Hércules con Ogmio, el dios de los celtas cuyo poder de persuasión era enorme. Según Luciano estaba representado por un viejo vigoroso, con maza, cubierto con la piel de león y de cuya boca salían cadenas de oro que, enganchadas a los oídos de quienes le escuchaban, hacían que éstos le siguieran. Erasmo, al traducir la obra de Luciano en 1512, rescató esta imagen, que no fue conocida en la Edad Media y Alciato la incluyó en sus Emblemas como símbolo de la elocuencia (fig. 7), pasando a ser tratada con idéntico simbolismo por otros autores como Aquiles Bocchio $^{43}$.

${ }^{42}$ A. ALLO, 1993, pp. 559-627.

${ }^{43}$ AlCiATO, op. cit., embl. CLXXX, p. 156. A. BOCCHI, op. cit., II, 43.
Atlas soportando dos globos, uno celeste con insignias eclesiásticas, como la tiara, la mitra y el capelo, y otro terrestre con una corona, el bastón de mando y la celada. Con el mote "Iuxta vires". (Toledo, 1642).

Atlas fue el gigante que encabezó a los Titanes en su lucha contra los dioses, por lo que fue condenado a llevar eternamente la bóveda celeste sobre sus hombros. $\mathrm{Su}$ representación es muy frecuente en la emblemática y en muchos grabados del s. XVII para simbolizar la pesada carga soportada por el monarca en el desempeño de su función; Juan de Borja con el lema "Liviano y de poca duración" se refiere a los trabajos y responsabilidades de esta vida, en comparación con el premio de la otra ${ }^{44}$. Por analogía, se comparó al gigante con el cardenal, apareciendo éste último como nuevo Atlas soportando su doble responsabilidad: la política, pues fue gobernador de Flandes, y la eclesiástica, dado que fue arzobispo de Toledo.

Ninfa Amaltea con dos cornucopias esparciendo flores y frutos, que se reponían constantemente desde el cielo. Con el mote "Quas dedit, habet". (Toledo, 1642). Significó la extrema liberalidad de D. Fernando de Austria.

Las Tres Gracias, diferenciadas por sus correspondientes guirnaldas de olivo, flores y espigas, portaban los tres blasones de D. Fernando de Austria -infante, cardenal-arzobispo, general-gobernador- e iban acompañadas de las inscripciones "Ex morte vita", "Ex labore requies" y "Ex bello pax". Les acompañaba el difunto representado como Febo resplandeciente, con el mote "Solem suum sua sydera noscunt" (Toledo, 1642).

\footnotetext{
${ }^{44}$ J. DE BORJA, op., cit., $1^{\underline{a}}$ parte, 6-7.
} 
Aglaya (majestad y hermosura), Talía (agrado) y Eufrosina (alegría y gozo); según el autor simbolizaron la grandeza del difunto como infante, arzobispo y gobernador. No cabe duda de que se trata de una iconografía un tanto recurrente si sólo atendemos a la explicación dada por su autor, pues no justifica la presencia de Apolo. La relación de este dios con las tres Gracias la encontramos en Cartari, quien explica, apoyándose en Macrobio, que los antiguos colocaron a las tres Gracias en la mano derecha de Apolo y un arco con flechas en la izquierda para simbolizar que la mano divina siempre está más dispuesta a hacer el bien que el mal ${ }^{45}$ (fig. 8).

Carro que, tras dejar al sol en poniente, retorna a por otro sol coronado que sale por oriente. Con el mote "Retro rediit Sol et addidit regi viam" y la letra "Quando va el Sol a espirar/Vuelve a nueva luz su rueda/ Para enseñar al que queda/ El camino de Reinar". (Corte, 1665) (fig. 9).

Es una bella imagen que muestra a Carlos II como nuevo dirigente de la monarquía, encontrando los mejores consejos para gobernar en las obras realizadas por su padre, Felipe IV. El tema tiene su fuente de inspiración en las Metamorfosis de Ovidio $^{46}$, describiendo los consejos que Febo dio a su hijo Faetón para guiar su carro, recomendándole seguir las huellas dejadas por sus ruedas en los días anteriores.

Dafne medio convertida en laurel protegiendo a un clavel situado a sus pies pero amenazado por rayos. Con el mote "Contemnit fulmina" y la letra "Pues le abriga con su sombra/ la que del Sol querida,/ no peligrará su vida". (Valencia, 1665).

El autor explica que el jeroglífico constituyó una imagen de la protección que

\footnotetext{
${ }^{45}$ V. CARTARI, op. cit. p. 471.

${ }^{46}$ OVIDIO, op. cit., II, 2.
}

gozaba Carlos II teniendo a la reina por tutora. Dafne simbolizaba a la reina "pues ambas fueron dos bellas mujeres amadas por el sol; el clavel designaba al joven príncipe "pues es hermoso como dicha flor y por sus pocos años es rey en flor". El jeroglífico se apoya en la peculiaridad del laurel de permanecer incólume ante los rayos, tal y como lo justifica Piero Valeriano, basándose en Plinio ${ }^{47}$.

Triunfo de la nave Argos (Universidad de Salamanca, 1665).

En el techo del primer cuerpo del túmulo se pintó la nave Argos con las armas reales en el mástil, abatida por un furioso mar embravecido por cuatro vientos con los escudos de Flandes, Nápoles, Cataluña y Portugal; entraba victoriosa en el cielo pasando a formar parte de una de sus constelaciones. Con el mote "Turbant, sed extoliunt".

Según su autor constituyó una imagen triunfal de la monarquía, guiada por el rey, luchando contra los cuatro problemas políticos más graves de su reinado. Este hermoso jeroglífico utiliza un símbolo de gran trascendencia en la literatura emblemática, pues son muchos los autores que emplean el tema de la nave para simbolizar el estado, la monarquía, aludiendo al rey como el capitán que la dirige y guía sorteando todo género de tempestades, de ahí que, subsidiariamente, también sea símbolo de la esperanza cercana ${ }^{48}$. En este sentido, quizás la imagen plástica más bella en la que ya había sido representado este significado, fue la gran nave Victoria que desfiló por las calles de Bruselas con motivo de las exequias reales de Carlos V en 1558. En cualquier caso, en nuestro jeroglífico se

\footnotetext{
${ }^{47}$ P. VALERIANO, op. cit., L.

${ }^{48}$ Diego López, en sus comentarios a los emblemas de Alciato, puntualiza que se trata de la república cristiana atravesando peligrosas tormentas.
} 
eligió una nave determinada, la de los argonautas, a tenor de las múltiples vicisitudes que éstos, guiados por Jasón, hubieron de librar en la búsqueda del vellocino de oro.

Júpiter y Felipe IV compartiendo el poder (Universidad de Salamanca, 1665).

Fueron representados como figuras de bulto y aparecieron coronando la cúpula del último cuerpo del túmulo, como remate de éste. El primero con un rayo en su mano $\mathrm{y}$ el segundo con el cetro, un águila real entre ambos, mientras soportaban un orbe monumental en el que se leía la inscripción "Júpiter y César comparten el Imperio".

Se trataba de una atrevida imagen de Felipe IV participando de todo el ejercicio del poder desde el cielo, junto a la mayor divinidad y de igual a igual. A pesar de tal triunfo, al autor le debió parecer poco, puesto que no dudó en afirmar: "Ni parece que se dio Júpiter por contento de este respetuoso convite, ni por pagado el difunto con tan cariñoso agasajo, sin duda porque aspiraban a más glorioso premio los méritos ventajosos de nuestro católico monarca; que el lucir en la eternidad de los justos es verdad que será en algo semejante al de las estrellas, pero no en todo, que éstas aún pueden padecer manchas y eclipses, y es la luz de los justos sin intercedencias y sin desmayos; su asiento aún ha de ser más sólido y más firme, donde no tenga el peligro de ellas de desquiciarse, ha de ser a par de Dios y servirse de las estrellas, de los signos y los planetas por alfombra de sus plantas $^{\prime 49}$.

Cuatro héroes míticos (Méjico, 1666)

\footnotetext{
${ }^{49}$ F. DE Roys, Pyra Real que erigió la Mayor Athenas a la Mayor Majestad. La Universidad de Salamanca a las Inmortales Cenizas, a la Gloriosa Memoria de su Rey y Señor D. Phelippe IV el Grande. Salamanca, 1666, p. 190.
}

Asimismo en Méjico fueron colocadas cuatro esculturas de bulto redondo en el segundo cuerpo del túmulo. Sus mayores excelencias fueron puestas en analogía con las correspondientes del difunto Felipe IV. Los personajes elegidos fueron: Teseo con un ovillo de lana, por la prudencia que guió al rey en sus primeros años de gobierno. Jasón con el vellocino de oro, por su constancia. Prometeo, llorando, por su sufrimiento ante las adversidades. Y por último, Jano con dos caras y un cetro rematado por un ojo, significando la vigilancia y prudencia sobre sus reinos más lejanos.

Ahora bien, aunque fueran las exequias del divino Felipe IV, el rey-sol por antonomasia, las que gozaron de un tratamiento mitológico más exhaustivo, ningún centro español concentró de una forma sistemática el uso de estas fuentes mitológicas en sus exequias reales como lo hizo la ciudad de Zaragoza. Y ello se debió al hecho de que la responsabilidad de erudición de sus correspondientes aparatos fúnebres siempre fue delegada por parte del concejo zaragozano al Colegio de la Compañía de Jesús. En efecto, los jesuitas zaragozanos fueron los responsables intelectuales de los aparatos de exequias reales en 1621, 1644, 1665, 1689, 1698 y 1700, es decir, de todas las honras fúnebres de personas reales fallecidos hasta el cambio de dinastía. Veamos algunos ejemplos.

En las exequias reales de Felipe III fueron elaborados 24 emblemas, de los que 14 , es decir, algo más del $50 \%$, ofrecieron un tema procedente de la Mitología Clásica. Constituyeron en su conjunto una de las reflexiones más completas que el siglo XVII nos ha legado en torno al concepto de la Muerte, como señora de los elementos, de las edades y de cualquier tipo de ocasiones, sobre su sentido de fatalidad, poder, incertidumbre, su rigor, la necesidad constante de meditación sobre su llegada, su triunfo sobre las cosas humanas y sobre el Amor, 
etc. Para ello fueron elegidos temas tales como la historia de Medea, las fábulas de Acteón, Faetón, la de Icaro, las muertes de Astianax a manos de Ulises, la de Esquilo, Palinuro, el sacrificio de Policena sobre la tumba de Aquiles, la muerte de Arquímedes en Siracusa, la de Diágoras, la de Layo por su hijo Edipo o las de Fabio y Anacreonte, etc.

Además de este interesantísimo conjunto emblemático, cuatro monumentales esculturas fueron dispuestas en las esquinas del túmulo. Representaban a César Augusto, Numa Pompilio, Alejandro Magno y Jano, cuyas cualidades mas representativas fueron parangonadas con Felipe III.

Como hemos comentado anteriormente, este programa iconográfico provocó violentas críticas en los círculos eruditos de la ciudad. Según se afirma en la relación, las obras que más polémica suscitaron fueron las cuatro esculturas de bulto, por tratarse de personajes paganos $\mathrm{y}$, por ello, resultar totalmente inadecuadas para un lugar donde se celebrarían oficios religiosos, pudiendo haber sido más oportuno la elección de reyes cristianos "pues a Aragón le sobran ejemplos". El jesuita responsable del programa se justificó apelando al uso, y para ello recordó la colocación de la divisa de Felipe II en 1598, así como a la actualidad de aquellos temas, ya que de igual forma lo había hecho la Villa de Madrid en estas mismas exequias. Pero además, haciendo gala de toda su ironía apuntó: “y como se pusieron otros emblemas pintados tomados de fábulas o historias gentilicias en que ninguno reparó, así se pusieron estatuas de bulto, ¿debió estar el hierro y diferencia en ser unos pintados y otros de todo relieve?". Y finalmente, dentro de la misma polémica, también afirma "no haber encontrado mejor medio que comparar a Felipe III con los príncipes a quienes la Antigüedad, verdadera estimadora de reales méritos, y el común sentir de excelen- tes escritores y la aprobación de edades y siglos, había tenido por los primeros en estas virtudes, y lo que dicho en un sermón en la iglesia no ofendiera, no hay razón para que escrito, esculpido o pintado se repruebe, pues tanto monta declarado de una u otra suerte si la significación es la misma" $^{\prime 50}$.

En las exequias de la reina Isabel de Borbón volvió a repetirse una situación similar. De los 23 emblemas y jeroglíficos que ornaron el lado de la epístola de la Seo zaragozana, ocho representaron temas tales como: Ceres, Aquiles disfrazado de mujer, Dafne convertida en laurel, Cupido, el monte Olimpo, Venus con el caduceo de Mercurio, Astrea, Cástor y Pólux; mientras que en el lado del evangelio figuraron: Flora, Pentesilea socorriendo a Troya, Juno plantando una azucena en la Vía Láctea, la historia de Leandro y Hero, y finalmente Amaltea. Todos ellos ejemplificaban virtudes y cualidades de la reina difunta. Veamos algunos ejemplos concretos.

Monte Olimpo, con su cumbre libre de nubes. Con el mote "Nubes excedit Olympus" y la letra "Fortaleza y honor son su vestidura" (Zaragoza, 1644). La cumbre del monte Olimpo no puede ser alcanzada por tempestades, por lo que pasó a ser símbolo de fortaleza y honor, tal como lo ejemplifica Hernando de Soto ${ }^{51}$.

Venus con el caduceo de Mercurio. Con el mote "Vel semel liceat" y la letra "Abrió su boca con sabiduría". (Zaragoza, 1644). Significó la unión de la belleza y el ingenio de la reina ${ }^{52}$.

${ }^{50}$ P. AlBINIANO DE RAJAS, op. cit., p. 102.

${ }^{51}$ H. DE SOTO, op. cit., embl. 26.

${ }^{52}$ V. CARTARI, op. cit. p. 454. Según Plutarco, resulta frecuente asociar las imágenes de Venus y Mercurio, para significar que, en la unión amorosa es importar conjugar el trato suave y dulce con las palabras agradables, para que nazca y se conserve el amor. 
Cástor y Pólux. Con el mote "Divisque, videbit per mixtos Heroas", y la letra "Levantaronse sus hijos y llamáronla bienaventurada". (Zaragoza, 1644). Aludió a sus sus dos hijos varones, reflejos dignos de su madre.

Flora cubriendo con flores el sepulcro de la reina. Con el mote "Te pereunte, perit". (Zaragoza, 1644). Apoyándose en la antigua tradición de esparcir flores sobre los sepulcros, el autor explica que el emblema aludía a los propios padres jesuitas disponiendo sus "flores poéticas" en el túmulo de la reina.

Pentesilea socorriendo a Troya. Con el mote "Mediisque in millibus ardet". (Zaragoza, 1644). Significó el socorro que procuró la reina a sus ejércitos. Su fuente de inspiración, tal como confirma el autor de la relación, fue el relato que hace Virgilio de esta valiente amazona en la Eneida, en donde explica que, a la muerte de Héctor, Pentesilea acudió en ayuda de Príamo al frente de un importante contingente de amazonas y se distinguió por numerosas hazañas en la guerra de Troya.

Juno plantando una azucena en la Vía Láctea. Con el mote "Digna Iovis proles". El autor, basándose en la fábula de la Vía Láctea, explica que el emblema mostraba a la reina-azucena convertida en estrella, tratándose en definitiva de una apoteosis en sentido clásico.

Finalmente, en las exequias reales de Felipe IV, trece de los 32 emblemas realizados fueron de temática mitológica y así, dentro de un contexto heroico, fueron representados los siguientes temas: Eneas ante el árbol dorado de la selva Aricina, para simbolizar la perpetuación de la monarquía; Perseo cortando la cabeza a la Medusa y Júpiter fulminando con sus rayos a los Gigantes, imágenes de Felipe IV domador de la herejía; Atlas con el orbe sobre sus hombros, símbolo del monarca soportando la grandeza de la Monarquía; el centauro Quirón alimentando con tuétanos de un león a Aquiles; las Náyades bebiendo agua en una fuente mientras vaciaban sus cántaros en la taza de la misma, aludiendo a la liberalidad del monarca en sus obras pías; Neptuno en su concha tirada por caballos marinos apaciguando con su tridente un airado mar, Europa sobre un toro con una lanza y un ramo de olivo en sus manos, ambas símbolo de Felipe IV como pacificador de Europa; arco iris en torno a una nube que llovía oro sobre la cuna de un niño, alusiva a la lluvia de oro provocada por Júpiter sobre la isla de Rodas cuando nació Minerva, para significar los beneficios que trajo el nacimiento de Carlos II; Hércules atacando el alcázar del rey Laomedonte y castigándole por su infidelidad, imagen de la represión de Nápoles por su sedición; Andrómeda entregando coronas a Perseo, símbolo de la defensa que el rey hizo de la Inmaculada Concepción de la Virgen; Belerofonte degollando a la Quimera, imagen del rey castigando la sedición de Sicilia; Nereida postrada a los pies de un majestuoso Neptuno, símbolo del arrepentimiento de Sicilia.

No es difícil concluir pensando tras este rápido repaso que, a pesar de la presencia indiscutible de la mitología en las composiciones iconográficas de estos programas funerarios, creciente además a medida que avanza el siglo XVII, los temas de asunto mitológico no llegaron a adquirir jamás una lugar destacado en tales conjuntos, a excepción de los ideados por la Compañía de Jesús, cuya afición por la fábula clásica permitió además una diversidad temática que es ajena a los programas ideados por otros eruditos. Quizás la razón fundamental fue un problema de "decoro", tal como lo revelan las críticas surgidas en Zaragoza en 1621 ante la proliferación de imágenes mitológicas en un lugar donde se 
celebrarían oficios religiosos. En esta misma línea de opinión se sitúa el propio padre Claude François Menestrier, reputado y conocido teórico de las decoraciones fúnebres, que a finales del siglo XVII afirma: "Il faut seulement prendre garde de ne rien introduire dans l'Eglise et dans les lieux saints, des misteres de la Fable et de la Theologie Payenne... Il faut donc bannir des eglises les representations de Junon, de Júpiter, de Mercure, d'Apollon, de Mars, de Venus, etc., et des autres fausses divinités, qui se pourroient soustrir en des decorations de colleges et d'Academies, où les Fables et la Posie ancienne sont reçues ${ }^{53}$.

En cualquier caso, el Colegio de la Compañía de Jesús de Zaragoza no debió tener muy en cuenta estas prudentes directrices. Es más, como se ha podido comprobar, el uso alcista de la mitología en las composiciones simbólicas de sus programas aparece directamente relacionado con la responsabilidad intelectual exclusiva de los propios padres jesuitas, siendo innegable en este sentido la potenciación y mantenimiento que hicieron de una parte muy delicada de la cultura clásica, cuya restricción en otros sectores de las artes plásticas es bien conocida.
Otra cuestión muy diferente es cómo fue utilizada la mitología en sus programas iconográficos. Se viene afirmando que, desde finales del siglo XVI y sobre todo durante el siglo XVII, la apropiación por los jesuitas de la cultura clásica para fines pedagógicos hizo estragos en el frágil compromiso vital del humanismo, es decir, parece evidente que se trivializó la utilización de las fuentes con objeto de llegar a un público cada vez más amplio ${ }^{54}$. Casos puntuales como el jeroglífico mejicano de las exequias de Carlos II parece confirmarlo sin explicaciones más allá de su propia lectura (fig. 10).

No obstante, y desde mi personal perspectiva, la rotundidad de tales afirmaciones no pueden construirse sobre ejemplos aislados y no creo que estén todavía bien definidos y valorados los resultados obtenidos en este proceso de reutilización de la cultura clásica. Pero resulta evidente que ésta es una cuestión que excede los propósitos de este artículo y que precisa de otros análisis y evaluaciones todavía pendientes.

\footnotetext{
${ }^{53}$ J.C.F. MENESTRIER, Les décorations fúnebres, Paris, 1684, p. 6.

${ }^{54}$ M. PrAz, "Lo agradable y lo útil”, Estudios de Emblemática. Imágenes del Barroco, Madrid, 1989, pp. 195-232.
} 

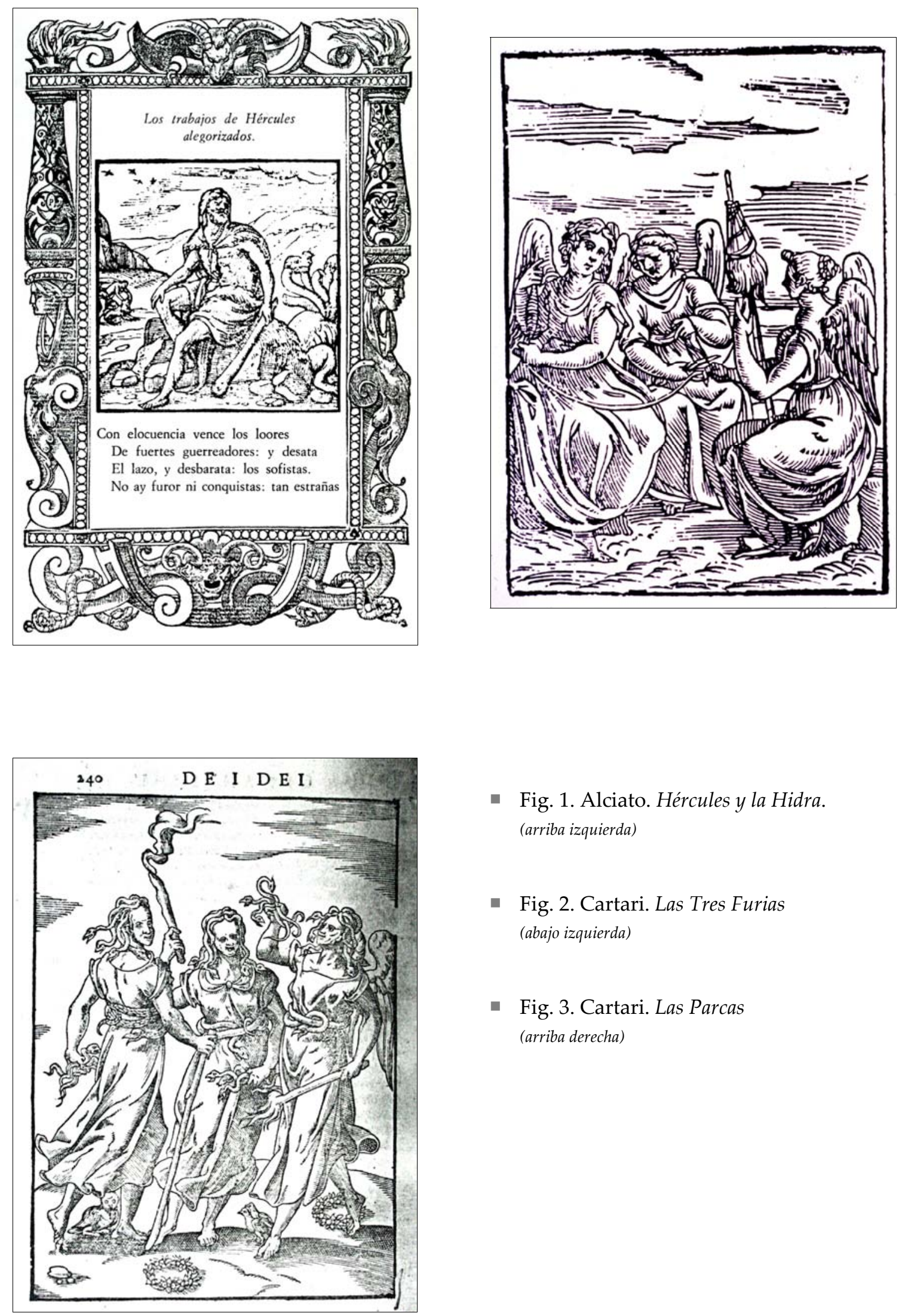

- Fig. 1. Alciato. Hércules y la Hidra. (arriba izquierda)

- Fig. 2. Cartari. Las Tres Furias (abajo izquierda)

- Fig. 3. Cartari. Las Parcas (arriba derecha) 

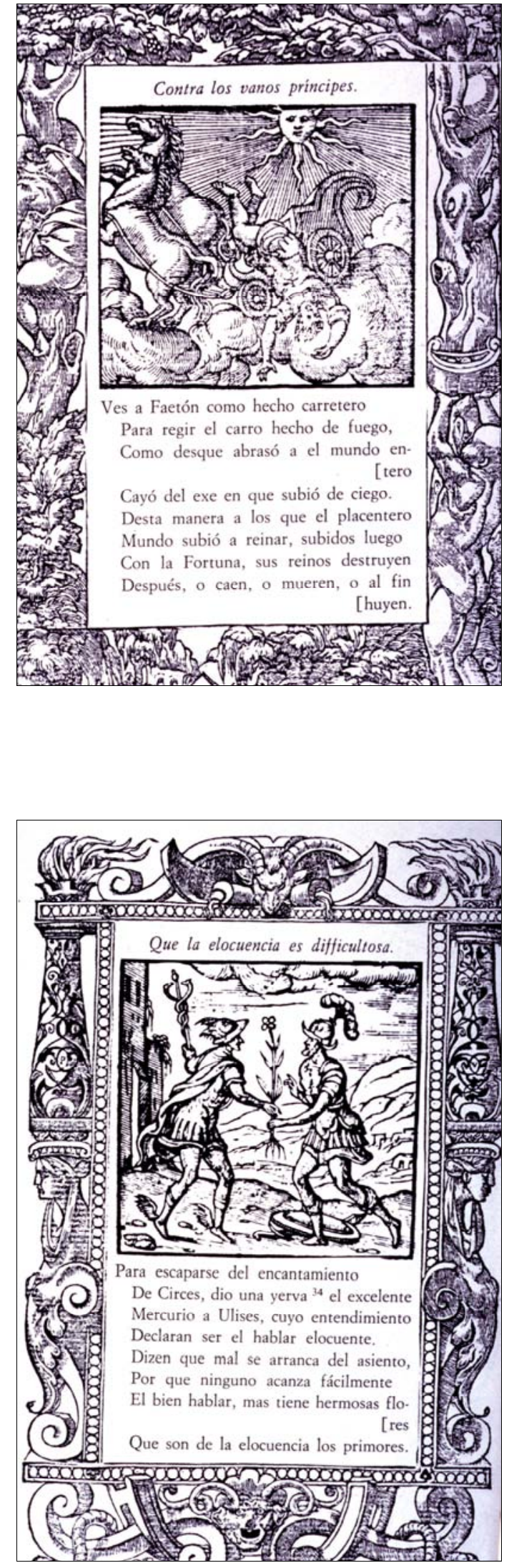

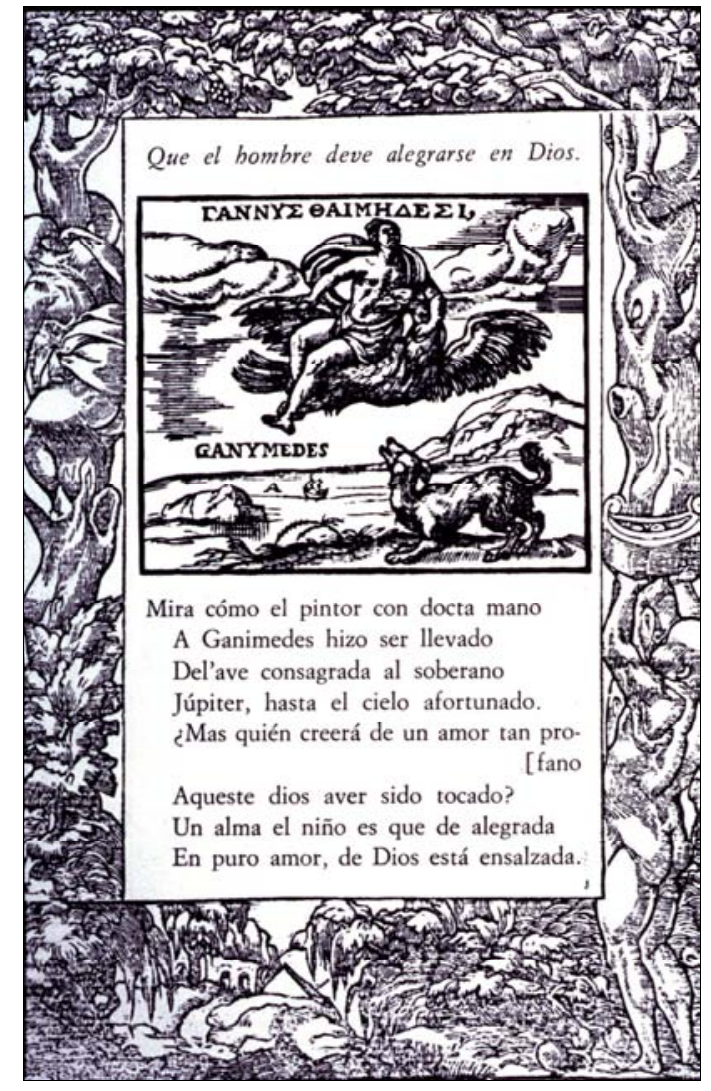

- Fig. 4. Alciato. Faetón. (arriba izquierda)

- Fig. 5. Alciato. Mercurio (abajo izquierda)

- Fig. 6. Alciato. Ganímedes (arriba derecha) 

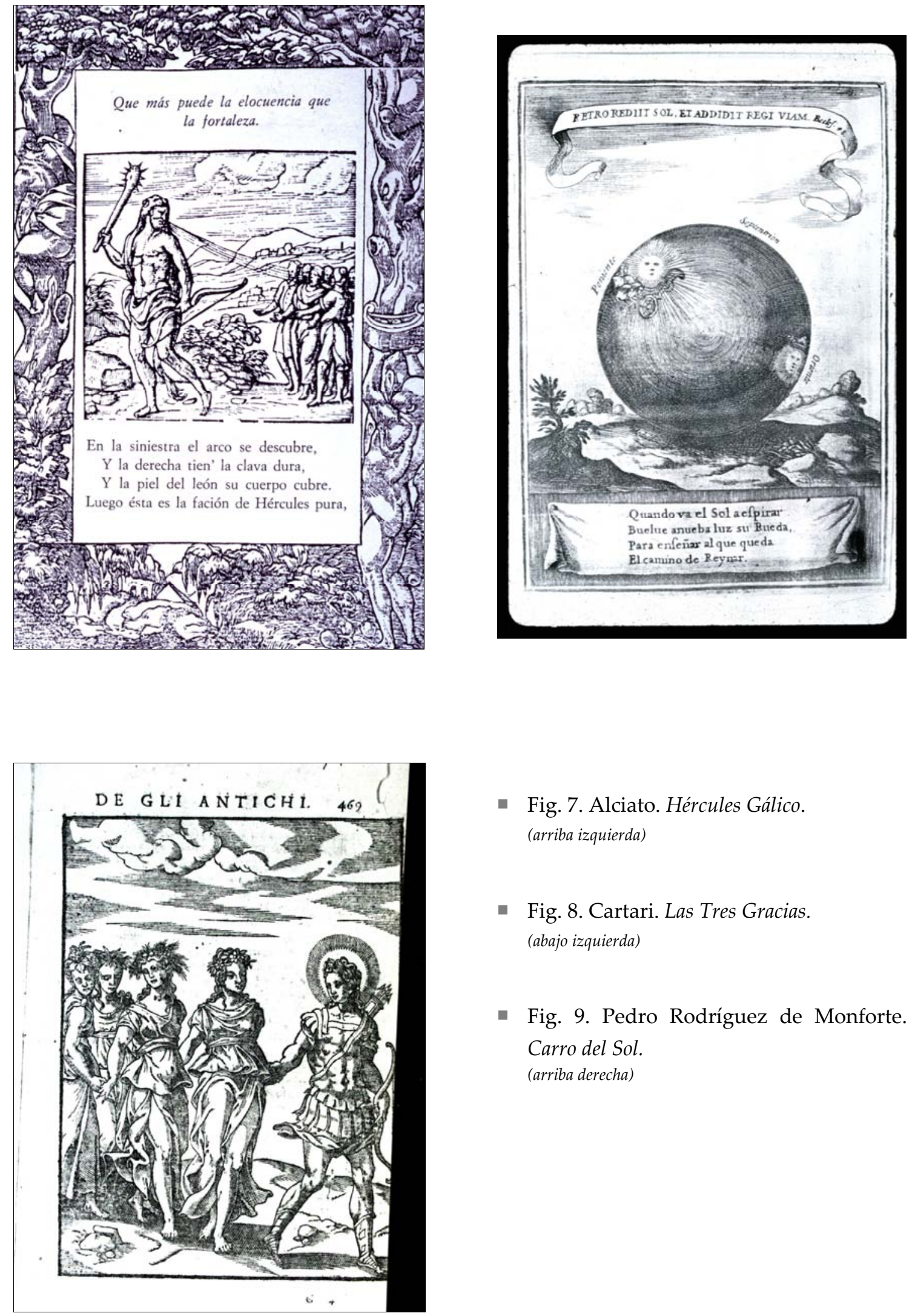

- Fig. 7. Alciato. Hércules Gálico. (arriba izquierda)

- Fig. 8. Cartari. Las Tres Gracias. (abajo izquierda)

- Fig. 9. Pedro Rodríguez de Monforte. Carro del Sol.

(arriba derecha) 


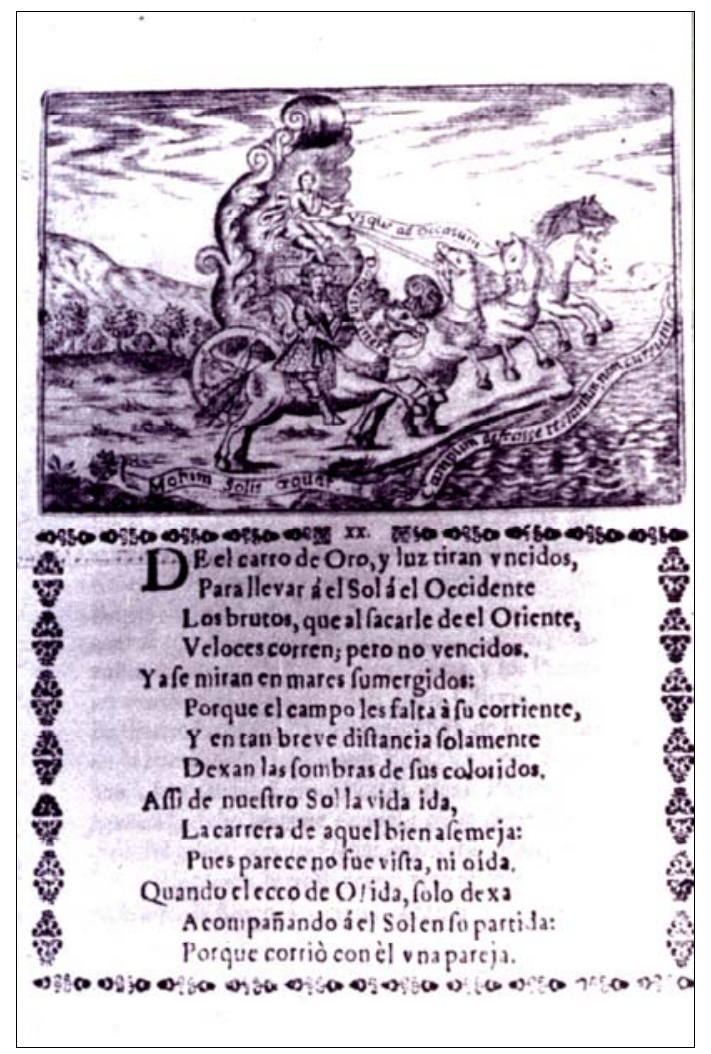

- Fig. 10. Agustín de Mora. Carro del Sol. (arriba centro) 